\title{
AIR POLLUTION BASED HEALTH CARE SYSTEMS
}

Dr. S. Veena

Professor

Department of CSE

S.A. Engineering College, Thiruverkadu, Chennai,

Tamil Nadu, India.

\author{
P.Vignesh \\ UG Student,
}

Department of CSE

S.A. Engineering College, Thiruverkadu, Chennai,

Tamil Nadu, India.

Abstract - This paper is all about the healthcare system that exist already and a brief comparison between them. The health effects related to air pollution are monitored and reported in a healthcare system. These systems are designed in order to monitor the indoor as well as the outdoor air pollution. WHO (World Health Organization) claims that the hazards that come through air pollution are increasing day by day and the main cause for these are vehicles, factories and emission of harmful gases into the atmosphere. Various reports suggest that air pollution exposure for longer time can lead to many respiratory problems. Data that is collected by the organization about air pollution has to be utilized very effectively. In this paper, we have analyzed the impact of air pollution on humans.

Keywords-Air Pollution, Diseases, Health care, Air quality.

\section{INTRODUCTION}

One of the main problems that is faced by modern people is air pollution and it is also one of the important aspect of healthcare [1] and also one of the big issue that has to be addressed in most of the developed countries. People nowadays are not aware of the environment they live in, and this problem is one among the main concerns about air pollution. Many countries have laws related to environment and healthcare [2]. There has been many studies related to air pollution and its effect on health of human. Many issues exist which has to be taken care of to make our surrounding pollution free. Sources of air pollution include smoke, vehicular smoke, natural gases and burning of fossil fuels,

Long term exposure to air pollution can lead to various health issues including cardiac attack, asthma and other respiratory problems. Color based indication of the air pollution is available through which people can take necessary steps based on the amount of air pollution[4].In order to overcome

\author{
T.Thomas Santhana Vijay \\ UG Student, \\ Department of CSE \\ S.A. Engineering College, \\ Thiruverkadu, Chennai, \\ Tamil Nadu, India.
}

\author{
Suriya Magesh Kumar \\ UG Student, \\ Department of CSE \\ S.A. Engineering College, \\ Thiruverkadu, Chennai, \\ Tamil Nadu, India.
}

all these problems related to air pollution, there has to be an effective system to monitor the air pollution [2].

\section{Issues That Has To Be AdDRessed In AIR POLLUTION}

A. Data on air pollution: The statistical data that is collected from various regions are very important to study the air quality. Though many gases are present in air mainly lead, carbon monoxide, sulfur dioxide, nitrogen dioxide, ozone and carbon dioxide are harmful for human health. AQI (Air Quality Index) provides the index of air and acts as a standard to calculate air quality.

B. Air pollution and its effect on health care: Air pollution can have both long term as well as short term health effects. It has mainly affected children and elderly which has effects on eyes, nose and throat as well. It has also given respiratory problems, allergic reactions and headache in severe cases.

C. Air pollution and environmental effects: Air pollution is one of the reasons for climate changes around the world. It has caused acid rain, smog and also depletes ozone layer which acts as a protection from harmful UV rays. It has a direct effect on soil, water and also harms trees which gives us oxygen. Wildlife and humans are getting affected by it on daily basis.

D. Human causes for air pollution: Humans are one of the main reasons for air pollution. Huge population, smoke that is released from industries, vehicles are the major contribution for air pollution. Human caused forest fire, energy production has resulted in more and more pollution.

E. Natural Causes for air pollution: Natural causes contribute only minimal air pollution than humans, it cannot be neglected. Natural causes include volcanic eruption, forest fires, ozone ground level zero are some of the reasons for air pollution. 


\section{International Journal of Engineering Applied Sciences and Technology, 2020 \\ Vol. 4, Issue 10, ISSN No. 2455-2143, Pages 80-83 \\ Published Online February 2020 in IJEAST (http://www.ijeast.com)}

F. Indoor and outdoor air pollution: The air quality that exists inside a building or infrastructure is called indoor air pollution and outdoor pollution is vice-weatherperson it is home any other place the traces of gases can be seen but in a minimal amount, encase of any gas leakage this trace can elevate. In outdoor mostly all the gases can be seen in mixture but places near industries can have high traces of toxic gases.

\section{SURVEY ON EXISTING SYSTEMS}

The following are the existing works:

Vincenzo Di Leece, Alberto Amato and Claudio Martines[2] has presented an intelligent distributed system which is designed to monitor the air quality in indoor environment.Low cost sensors are used and they are equipped with communication modules. A multi agent system handles the aspects of the system which monitors. These aspects are: Data analysis, data integration and user centered interfaces.

Quan Dong, Baichen Li, R. Scott Downen, Nam Tran, Elizabeth Chorvinsky, Dinesh Pillai, Mona Zaghloul, Zhenyu $\mathrm{Li}[5]$ has proposed a system which acts as a wearable and stationary point of care for pediatric asthma research. It is a cloud based wearable which helps in measuring the asthma patients exposure to various gases such as O3(Ozone),NO2(Nitrogen Di Oxide) and other aldehydes in real life setting. The levels of these gases that can be measured are between $30 \mathrm{ppb}$ and $10 \mathrm{ppm}$. It helps in studies of asthma and environmental monitoring.
Kin-Fai Ho, Hoyee W Hirai, Yong-Hong Kuo, Helen M Meng and Kelvin KF Tsoi [9] has proposed a system which is used to monitor indoor air and generate health reports based on the air quality. The data will be captured and stored in cloud to enhance storage of data and improve computational efficiency. A self reporting system is implemented so that the user can self upload the report onto the cloud for analysis. This data can be used to take precautions which can help the user to avoid inhaling of any harmful gases.

Mostafizur Rahaman Laskar, Prasanta kr Sen, Shyamal Kumar Das Mandal [10] has proposed a system which integrates both IOT and wireless sensor networks. It is an embedded application which is designed especially for people who are more concerned about air pollution. This system uses Google maps API for navigation and localization. It generates the optimal route through which a user can travel to avoid air pollution. The route is computed using wireless LAN based on cloud servers.

P T Nithia and S. Ullas [11] has proposed a health advisory system for homemakers with various sensors. In this system, the concentration of various harmful gases present in the kitchen like, methane, ethane, carbon dioxide etc are monitored. If these harmful gases reach or cross certain level then a warning message will be sent to the homemaker via an android app and the user can turn on exhaust fan or open windows or even inform others in case of emergency or even inform neighbors.

\section{COMPARISON OF TECHNOLOGIES USED IN AIR POLLUTION BASED HEALTH CARE SYSTEMS}

\begin{tabular}{|c|c|c|c|c|}
\hline S.NO & TITLE & TECHNOLOGIES USED & ADVANTAGES & DISADVANTAGES \\
\hline 1 & $\begin{array}{l}\text { Air Quality Control for Health } \\
\text { Care Centers. The } \\
\text { Application of an Intelligent } \\
\text { Distributed System }\end{array}$ & Distributed Systems & $\begin{array}{l}\text { Can handle various } \\
\text { aspects of monitoring. } \\
\text { Low cost sensors are } \\
\text { used for } \\
\text { communication. }\end{array}$ & $\begin{array}{l}\text { High cost sensors for air } \\
\text { quality sensing. }\end{array}$ \\
\hline 2 & 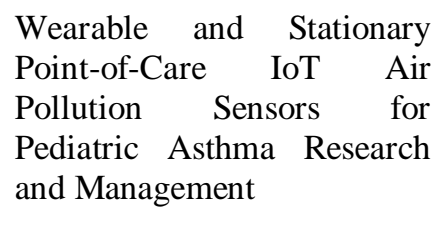 & IOT and cloud computing & $\begin{array}{l}\text { A wireless smart } \\
\text { device is designed to } \\
\text { monitor asthma } \\
\text { patients. } \\
\text { It can be used }\end{array}$ & $\begin{array}{l}\text { This system is meant } \\
\text { only for asthma patients } \\
\text { not for any other } \\
\text { respiratory problem. }\end{array}$ \\
\hline
\end{tabular}




\begin{tabular}{|c|c|c|c|c|}
\hline & & & $\begin{array}{l}\text { anywhere and can be } \\
\text { taken anywhere by the } \\
\text { user. }\end{array}$ & \\
\hline 3 & $\begin{array}{l}\text { Indoor Air Monitoring } \\
\text { Platform and Personal Health } \\
\text { Reporting System }\end{array}$ & $\begin{array}{l}\text { IOT, cloud computing and Big } \\
\text { Data }\end{array}$ & $\begin{array}{l}\text { The accumulated data } \\
\text { can be used in the field } \\
\text { of research of public } \\
\text { health. }\end{array}$ & $\begin{array}{l}\text { It is used only in indoor } \\
\text { air quality monitoring. } \\
\text { It can be extended } \\
\text { outdoors to be more } \\
\text { effective. }\end{array}$ \\
\hline 4 & $\begin{array}{l}\text { An IoT-Based e-Health } \\
\text { System Integrated With } \\
\text { Wireless Sensor Network and } \\
\text { Air Pollution Index }\end{array}$ & $\begin{array}{l}\text { IOT and Wireless sensor } \\
\text { networks }\end{array}$ & $\begin{array}{l}\text { Based on the traveling } \\
\text { of the user the most } \\
\text { optimized and } \\
\text { pollution less route is } \\
\text { calculated. }\end{array}$ & $\begin{array}{l}\text { Lacks in disease } \\
\text { specific } \\
\text { recommendations for } \\
\text { users, the route is given } \\
\text { in general. }\end{array}$ \\
\hline 5 & $\begin{array}{lcr}\text { An IoT based } & \text { Safety \& } & \text { Health } \\
\text { Advisory } & \text { System } & \text { for } \\
\text { Homemaker } & \text { with } & \text { Service } \\
\text { Independence } & \text { on } & \text { Various } \\
\text { Sensors } & & \end{array}$ & IOT & $\begin{array}{l}\text { Leakage of harmful } \\
\text { gases can be sensed in } \\
\text { the kitchen and users } \\
\text { will be informed if the } \\
\text { gases are reaching a } \\
\text { threshold. }\end{array}$ & $\begin{array}{l}\text { The sensing is restricted } \\
\text { only to the kitchen and it } \\
\text { cannot specify which } \\
\text { gas is leaking. }\end{array}$ \\
\hline
\end{tabular}

\section{CONCLUSION}

In this paper, a comparison between the existing system has been made along with the advantages and disadvantages of each of the systems that exist. There are various ways in which air pollution can be monitored and it can also be disease specific and various technologies can be used to implement the systems. We have also discusses about the issues that has to be addressed in air pollution to obtain a healthy environment. So we conclude that there has to be a continuous monitoring of the air pollution and it must also create awareness among people about their surroundings to make everyone healthier.

\section{ACKNOWLEDGEMENT}

We sincerely thank the management of S.A Engineering college, advisor, principal and faculty members for guiding us in doing our research and motivating us to do more such researches in future.

\section{REFERENCES}

[1] Bjørn Sætterstrøm, Marie Kruse, Henrik BrønnumHansen, Jakob Hjort Bønløkke, Esben Meulengracht Flachs, and Jan Sørensen(2012),"A Method to Assess the Potential Effects of Air Pollution Mitigation on Health care Costs",Hindawi Publishing Corporation Journal of
Environmental and Public Health Volume 2012, Article ID 935825, DOI:10.1155/2012/935825

[2] Vincenzo Di Leece, Alberto Amato, Claudio Martines(2009),"Air Quality Control for Health Care Centres. The Application of an Intelligent Distributed System", October 2009, DOI: 10.1109/EESMS.2009.5341321

[3]george d. thurstona, marni y.v. bekkedalb, eric m. robertsc, kazuhiko ito a, c. arden pope iiid, barbara s. glenne, halu^ ko“" zkaynakf and mark j. utellg(2008),"Use of health information in air pollution health research: Past successes and emerging needs", October 2008, DOI: 10.1038/jes.2008.41

[4] Adel Ghorani-Azam, Bamdad Riahi-Zanjani, Mahdi Balali-Mood(2016),'Effects of air pollution on human health and practical measures for prevention in Iran", Journal of reasearch in medical sciences(JRMS), 2016, Volume 21, Number 5, DOI: 10.4103/1735-1995.189646

[5] Quan Dong, Baichen Li, R. Scott Downen, Nam Tran, Elizabeth Chorvinsky, Dinesh Pillai, Mona Zaghloul, Zhenyu Li(2019),"Wearable and Stationary Point-of-Care IoT Air Pollution Sensors for Pediatric Asthma Research and Management", 2019 IEEE Healthcare Innovations and Point of Care Technologies, (HI-POCT), DOI: 10.1109/HIPOCT45284.2019.8962865.

[6]Ruzena Bajcsy(2010),"A Wireless Body Sensor Network for Different Health Related Applications", 2010 IEEE International Conference on Sensor Networks, Ubiquitous, and Trustworthy Computing ,DOI: 10.1109/SUTC.2010.76. [7]A. C. M. Fong, B. Fong(2010),"Prognostic Health Management for Environmental Monitoring",2010 IEEE 
International Conference on Management of Innovation \& Technology, DOI: 10.1109/ICMIT.2010.5492813.

[8]eleni fotopoulou,, anastasios zafeiropoulos, dimitris papaspyros, panagiotis hasapis, george tsiolis, thanassis bouras, spyros mouzakitis, and norma zanetti(2015),"Linked Data Analytics in Interdisciplinary Studies: The Health Impact of Air Pollution in Urban Areas", Digital Object Identifier 10.1109/ACCESS.2015.2513439.

[9]Kin-Fai Ho, Hoyee W Hirai, Yong-Hong Kuo, Helen M Meng, Kelvin KF Tsoi(2015),'Indoor Air Monitoring Platform and Personal Health Reporting System",2015 IEEE International Congress on Big Data, DOI: 10.1109/BigData Congress.2015.51.

[10]Mostafizur Rahaman Laskar,Prasanta kr Sen, Shyamal Kumar Das Mandal(2019),”An IoT-Based e-Health System Integrated With Wireless Sensor Network and Air Pollution Index”, 2019 Second International Conference on Advanced Computational and Communication Paradigms (ICACCP) ,DOI: 10.1109/ICACCP.2019.8882985

[11] P T Nithia, S. Ullas(2018),"An IoT based Safety \& Health Advisory System for Homemaker with Service Independency on Various Sensors",2018 Second International Conference on Inventive Communication and
Computational Technologies(ICICCT), DOI: 10.1109/ICICCT.2018.8473143

[12]Carmen C. Y. Poon, Wenbo Gu, and Y. T. Zhang(2010),'Health Informatics for Low-Cost and HighQuality Health Care",Conference proceedings: Annual International Conference of the IEEE Engineering in Medicine and Biology Society. IEEE Engineering in Medicine and Biology Society. Conference 2010:1755-8, DOI: 10.1109/IEMBS.2010.5626726

[13]xiaolin xia and ling yao(2019),"Spatio-Temporal Differences in Health Effect of Ambient PM2.5 Pollution on Acute Respiratory Infection Between Children and Adults",IEEE Access (Volume:7), DOI: 10.1109/ACCESS.2019.2900539

[14]M.A. Reyna-Carranza, J. V. Mérida-Palacio, C. SoriaRodriguez(2010),"Acute Effects of the PM10 and O3 in the Healthy School Children Pulmonary Function from Mexicali, BC, Mexico",2010 Pan American Health Care Exchanges, DOI: 10.1109/PAHCE.2010.5474617

[15]Sung Kyun Park, Marie S. O’Neill, Pantel S. Vokonas, David Sparrow, and Joel Schwartz(2005),"Effects of Air Pollution on Heart Rate Variability",DOI:10.1289/ehp.7447 